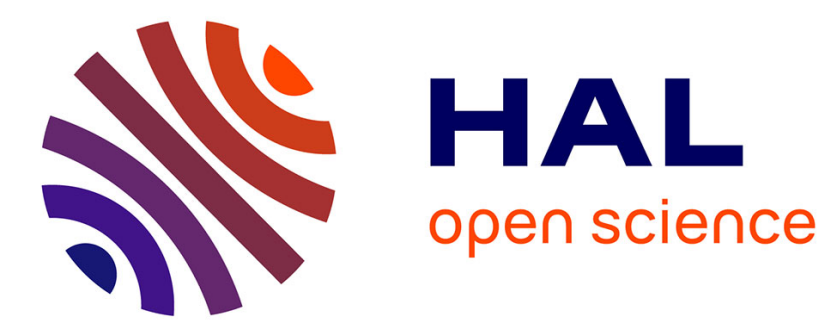

\title{
The Effect of Hydrostatic Pressure on the Local Structure of K1-xNaxTaO3 and KTa1-xNbxO3
}

\author{
F. Wang, B. Ravel, Y. Yacoby, E. Stern, R. Ingalls
}

\section{To cite this version:}

F. Wang, B. Ravel, Y. Yacoby, E. Stern, R. Ingalls. The Effect of Hydrostatic Pressure on the Local Structure of K1-xNaxTaO3 and KTa1-xNbxO3. Journal de Physique IV Proceedings, 1997, 7 (C2), pp.C2-1225-C2-1226. 10.1051/jp4:19972205 . jpa-00255277

\section{HAL Id: jpa-00255277 https://hal.science/jpa-00255277}

Submitted on 1 Jan 1997

HAL is a multi-disciplinary open access archive for the deposit and dissemination of scientific research documents, whether they are published or not. The documents may come from teaching and research institutions in France or abroad, or from public or private research centers.
L'archive ouverte pluridisciplinaire HAL, est destinée au dépôt et à la diffusion de documents scientifiques de niveau recherche, publiés ou non, émanant des établissements d'enseignement et de recherche français ou étrangers, des laboratoires publics ou privés. 


\title{
The Effect of Hydrostatic Pressure on the Local Structure of $\mathrm{K}_{1-x} \mathrm{Na}_{x} \mathrm{TaO}_{3}$ and $\mathrm{KTa}_{1-x} \mathrm{Nb}_{x} \mathrm{O}_{3}$
}

\author{
F. Wang, B. Ravel, Y. Yacoby, E.A. Stern and R. Ingalls
}

Department of Physics, FM-15, University of Washington, Seattle WA 98195, U.S.A.

\begin{abstract}
We report the effect of hydrostatic pressure on the local structural distortions in $\mathrm{K}_{0.15} \mathrm{Na}_{0.85} \mathrm{TaO}_{3}$ and $\mathrm{KNb}_{0.87} \mathrm{Ta}_{0.13} \mathrm{O}_{3}$. The results show that as expected the unit cell dimensions and the $\mathrm{Nb}$ off center displacements decrease with increasing pressure. In contrast the oxygen rotation angles in $\mathrm{K}_{0.15} \mathrm{Na}_{0.85} \mathrm{TaO}_{3}$ increase with pressure. We also observe an anomalous increase in the $\mathrm{Nb}-4$ th oxygen Debye-Waller factor which shows that pressure can induce disordered oxygen octahedra rotations in a crystal with no such rotations at ambient pressure.
\end{abstract}

\section{Introduction}

The existence of local disordered structural distortions in the high symmetry phase of crystals undergoing structural phase transitions has by now been firmly established. In particular Xray Absorption Fine Structure (XAFS) measurements have established that local distortions are present in the high symmetry phases of crystals undergoing ferroelectric $[1,2,3]$, antiferroelectric[4] and antiferrodistortive phase transitions[5]. These results show that the local distortions are not a result of the structural phase transitions, instead they may be involved in causing them.

Recently, Girschberg and Yacoby[6] showed that a model based on the existence of a soft mode, spontaneous off center ion displacements and their interaction account for a number of different experiments which could not be properly explained on the basis of displacive type theories.

It is well known that hydrostatic pressure affects the transition temperature and the type of structural phase transitions. To further investigate the role of the local distortions we started investigating the effect of pressure on the local structure.

\section{Experimental.}

The measurements reported here have been done on two materials: $\mathrm{K}_{0.15} \mathrm{Na}_{0.85} \mathrm{TaO}_{3}$ and $\mathrm{KNb}_{0.87} \mathrm{Ta}_{0.13} \mathrm{O}_{3}$. At room temperature, the first material has an antiferrodistortive distortion while the second is ferroelectric. In this preliminary study we investigated the effect of pressure on these distortions. The probes used were Ta and Nb in $\mathrm{K}_{0.15} \mathrm{Na}_{0.85} \mathrm{TaO}_{3}$ and $\mathrm{KNb}_{0.87} \mathrm{Ta}_{0.13} \mathrm{O}_{3}$ respectively. The samples were prepared by mixing fine powders of the crystals (a few microns in diameter) with Copper powder and grease. The copper was used to calibrate the pressure. The quantities were chosen so as to obtain an edge jump of 1.5 for the crystals and 1 for the copper. The XAFS measurements were done at the X11a beam line at NSLS in transmission mode. The experimental set up has been previously described[7]. In order to reduce systematic errors, a fine iris was placed before the reference detector. The iris was prepared by carefully piercing a round hole in a $1.5 \mathrm{~mm}$ thick $\mathrm{Pb}$ foil. The diameter of the hole was smaller than the hole in the gasket so that the beam which went through this iris went clear through the reference detector the sample and the signal detector. This provided a relatively good XAFS signal. The anvils were made of boron carbide with a tip diameter of $2 \mathrm{~mm}$ and a gasket hole diameter of $0.75 \mathrm{~mm}$

\section{Results and discussion.}

To minimize the error in calibrating the pressure we carried out one copper XAFS measurement in between two crystal measurements all at the same nominal pressure. The average of the two crystal XAFS spectra was then used for further analysis. An example of the absolute value of Fourier transforms of the XAFS signal of $\mathrm{KNb}_{0.87} \mathrm{Ta}_{0.13} \mathrm{O}_{3}$ is shown in Fig. 1. The data analysis method has been previously described in detail[ $[1,3]$ and will not be repeated here. The details pertinent to the present experiments are as follows: The pressure was calibrated using the Copper XAFS data. The copper experimental FT spectra were fit in real space in the range $1.5<r<5.5 \AA$ which includes 5 shells and all the relevant single double and triple scattering configurations. Special attention was paid to line up the absorption edges since the X11a spectrometer is known to have small errors of a few eV when making fast large changes in energy. In these analyses we used altogether 13 parameters including 5 Mean Squared Relative Displacements (MSRD's), 5 phase correction parameters, the threshold energy $E_{0}$, an overall amplitude and the unit cell dimension. The phase correction parameters, $E_{0}$ and the amplitude were not allowed to vary with pressure. The hydrostatic pressure values were obtained from the changes in the copper unit cell with an error bar of $\pm 2 k b a r$.

The XAFS spectra of $\mathrm{K}_{0.15} \mathrm{Na}_{0.85} \mathrm{TaO}_{3}$ and $\mathrm{KNb}_{0.87} \mathrm{Ta}_{0.13} \mathrm{O}_{3}$ were both fit in the range $1.0<r<4.1 \AA$. An example of the fits are shown in Fig. 1. Due to systematic errors, which are larger than in ambient pressure experiments, the quality of these fits is not as good as those obtained at ambient pressure. The parameters used in these fits were 
as follows: 4 MSRUs, 4 phase corrections $E_{0}$, amplitude and the unit cell. In addition in $\mathrm{KNb}_{0.87} \mathrm{Ta}_{0.13} \mathrm{O}_{3}$ we varied the $\mathrm{Nb}$ off center displacement and in $\mathrm{K}_{0.15} \mathrm{Na}_{0.85} \mathrm{TaO}_{3}$ we varied the oxygen octahedra rotation angle. The number of independent experimental points relevant to the fit ranges in the real and reciprocal spaces was 23 , namely much larger than the number of fit parameters.

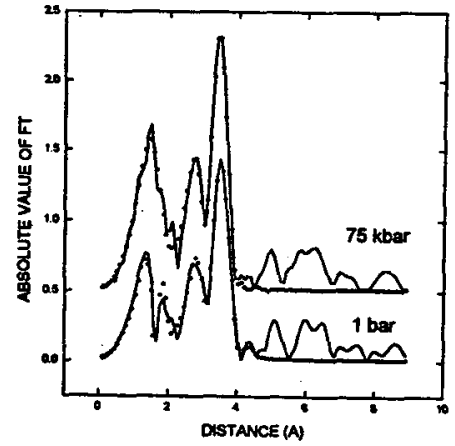

Fig. 1. Absolute value of the Fourier transform of the XAFS spectra of $\mathrm{KNb}_{0.87} \mathrm{Ta}_{0.13} \mathrm{O}_{3}$. Experiment - solid line, Theory - dotted line.

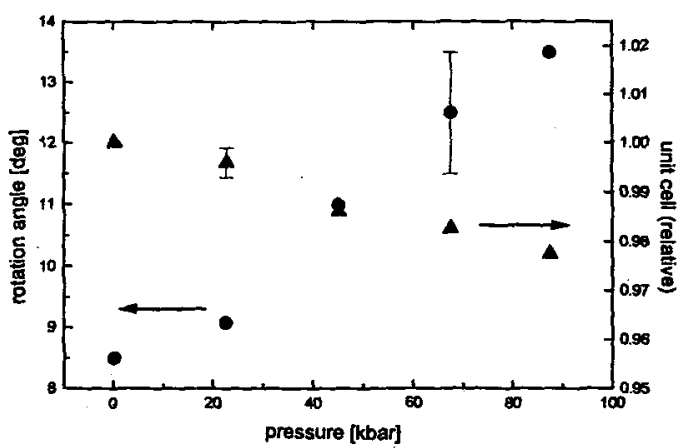

Fig. 2. $\mathrm{K}_{0.15} \mathrm{Na}_{0.85} \mathrm{TaO}_{3}$. Pressure dependence of the ratio between the unit cell under pressure and at ambient pressure (triangles) and the oxygen rotation angles (dots).

The pressure dependence of the important structural parameters of $\mathrm{K}_{0.15} \mathrm{Na}_{0.85} \mathrm{TaO}_{3}$ and $\mathrm{KNb}_{0.87} \mathrm{Ta}_{0.13} \mathrm{O}_{3}$ are shown in Figs. 2 and 3 respectively. As expected both unit cell dimensions decrease with increasing pressure. The $\mathrm{Nb}$ - oxygen distance also decreases with increasing pressure. This is consistent with the tendency of ferroelectrics to become paraelectric at high hydrostatic pressures. On the other hand the oxygen rotation angle increases with pressure. This behavior is similar to the behavior found in $\mathrm{ReO}_{3}[8]$.

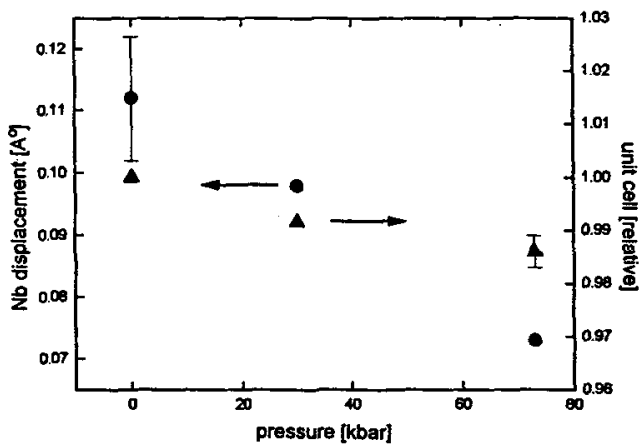

Fig. 3. $\mathrm{KNb}_{0.87} \mathrm{Ta}_{0.13} \mathrm{O}_{3}$. Pressure dependence of the ratio between the unit cell under pressure and at ambient pressure (triangles) and of the $\mathrm{Nb}$ off center displacements (dots).

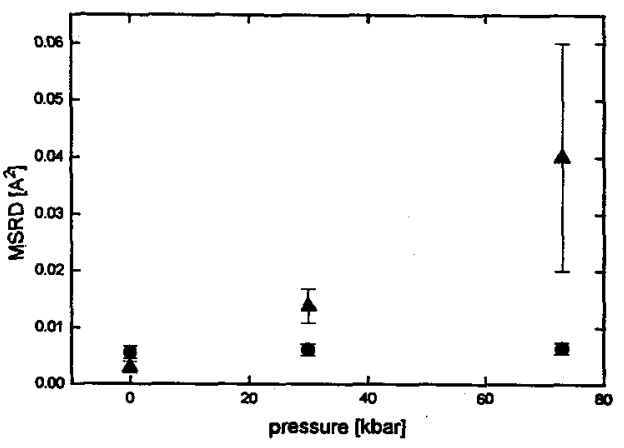

Fig. 4. $\mathrm{KNb}_{0.87} \mathrm{Ta}_{0.13} \mathrm{O}_{3}$. Pressure dependence of the MSRDs of the $\mathrm{Nb}$ - Ist shell oxygens (dots) and of the $\mathrm{Nb}-4$ th shell oxygens (triangles).

The $\mathrm{Nb}$ - 4th oxygen MSRD has an anomalous behavior with pressure. The pressure dependence of the MSRD of $\mathrm{Nb}$ probe relative to the 1st and 4th oxygen neighbors are shown in Fig. 4. The MSRD of Nb - 1st oxygen behaves as expected, namely it slightly decreases with increasing pressure. In contrast the MSRD of the Nb - 4th oxygen increases dramatically with pressure. This result can be understood if one assumes that pressure induces disordered oxygen octahedra rotations. In the first approximation the rotations do not affect the $\mathrm{Nb}-1$ st oxygen distances but they do affect the $\mathrm{Nb}$ - 4th oxygen distances thus contributing to a large MSRD. We tried to fit the results with oxygen octahedra rotated by a well defined angle instead of a large MSRD but this model did not give reasonable fits to the data.

References

[ 1] O. Hanske-petitierre, Y.Yacoby, J. Mustre-deLeon, E.A. Stern and J.J. Rehr, Phys. Rev., B44, 6700 (1991).

[ 2] Q.T. Islam and B.A. Bunker, Phys. Rev. Lett., 59 (1987) 2701.

[3] N. Sicron, B. Ravel, Y. Yacoby, E.A. Stern, F. Dogan and J.J. Rehr, Phys. Rev. B50, 13168 (1994).

[4] N. Sicron, Y. Yacoby and E.A. Stern, unpublished.

[5] B. Rechav, Y. Yacoby, E.A. Stern, J.J. Rehr and M. Newville. Phys. Rev. Lett., 72, 1352 (1994).

[6] Y. Girschberg and Y. Yacoby, unpublished.

[ 7] R. Ingalls, E.D. Crozier, J.E. Whitmore, A.J. Seary and J.M. Tranquada, J. Appl. Phys. 51, 3158 (1980).

[ 8] B. Houser, R. Ingalls and J.J. Rehr, Physica B208 \& 209, 323 (1995). 